\title{
Analysis of Decision Process to Buy Free-Range Eggs and the Implication on Marketing Mix (A Case Study to Wholesalers and Retailers Consumers in Traditional Markets in Purworejo District)
}

\author{
Zulfanita ${ }^{*}$, Roisu Eny Mudawaroch and Jeki Mediantari Wahyu Wibawanti \\ Department of Animal Science, Faculty of Agriculture, Universitas Muhammadiyah Purworejo Indonesia \\ *Email for corresponding author: tatazulfanita@yahoo.com
}

\begin{abstract}
This research aimed to compare the characteristics of free-range eggs consumers, to analyse their buying decision process and consumer satisfaction level, and to formulate the implication on free-range marketing mix across wholesalers and retailers in Purworejo districts. The research sample was 32 respondents, consisted of 16 wholesalers and 16 retailers selected with purposive sampling because of the limited number of respondents in each sub-district. The consumers were selected through snowball sampling from one respondent to another. The parameters included the general characteristics, the decision to buy free-range eggs, consumers' satisfaction level, and marketing mix implications. The Data were analysed descriptively using Chi-Square, Mann-Whitney Customer Satisfaction Index (CSI), and Importance and Performance Analysis (IPA). The result found different characteristics across consumers of free-range eggs in both wholesalers and retailers regarding age group, marital status, education background, gender, occupation, and geographic locations. The different process of buying decision making was due to need identification. Regarding gathering information, the wholesaler consumers relied on electronic media and their neighbours, whereas the retailer consumers only from their neighbours. The main consideration to purchase free-range eggs among wholesaler consumers was the cleanliness of eggs, whereas the retailer consumers were the cleanliness and price of eggs. The consumer satisfaction index on consumers in wholesalers and retailers was 65.16 and 68.82 , respectively, indicative of the satisfied category. The marketing mix implication on both sellers was improving the cleanliness of free-range eggs and the market area, matching selling price with the market price, controlling the quality of free-range eggs from the suppliers, and revisiting the supply system to ensure the real-time availability of free-range eggs.
\end{abstract}

Keywords: free-range eggs, consumer behaviour, marketing mix

\begin{abstract}
Abstrak. Tujuan penelitian ini adalah membandingkan karakteristik konsumen telur ayam buras, menganalisis proses keputusan pembelian dan tingkat kepuasan konsumen serta merumuskan implikasi bauran pemasaran telur ayam buras di pedagang Grosir dan pedagang pengecer kabupaten Purworejo. Sampel penelitian sebanyak 32 responden yang terdiri dari 16 pedagang grosir dan 16 pedagang pengecer. Pengambilan sampel pedagang grosir dan pengecer secara purposive sampling, disengaja dengan alasan terbatasnya responden di tiap kecamatan sedangkan konsumen dengan menggunakan Snowball Sampling yaitu teknik pengambilan sampel melalui proses bergulir dari satu responden ke responden lainnya. Parameter yang diukur yaitu karakteristik umum, keputusan pembelian telur buras, tingkat kepuasan konsumen dan implikasi bauran pemasaran. Alat analisis yang digunakan adalah analisis deskriptif, Chi-Square, Mann-WhitneyCustomer Satisfaction Index (CSI) dan Importance and Performance Analysis (IPA). Terdapat perbedaan karakteristik konsumen telur ayam buras pada pedagang grosir dan pengecer dari sebaran usia, status pernikahan, pendidikan, jenis kelamin, pekerjaan, dan lokasi geografis. Perbedaan proses pengambilan keputusan pembelian berasal dari pengenalan kebutuhan. Konsumen pada pedagang grosir mendapat informasi dari media elektronik dan tetangga, sedangkan konsumen pada pedagang pengecer dari tetangga. Pertimbangan utama dalam pembelian telur ayam buras untuk konsumen di pedagang grosir yaitu kebersihan telur sedangkan konsumen di pedagang pengecer yaitu kebersihan dan harga telur. Nilai yang diperoleh oleh konsumen pada pedagang grosir pada perhitungan indeks kepuasan konsumen sebesar 65,16 dan konsumen pada pedagang pengecer 68,82 dengan kategori puas. Implikasi bauran pemasaran pada kedua pedagang adalah meningkatkan kebersihan telur ayam buras serta area penjualan, menetapkan harga sesuai dengan harga pasaran, melakukan pengecekan terhadap kualitas telur ayam buras dari pemasok serta mengelola kembali sistem persediaan produk untuk menjamin ketersediaan telur ayam buras setiap saat.
\end{abstract}

Kata kunci: Telur Ayam Buras, Perilaku Konsumen, Bauran Pemasaran 


\section{Introduction}

Livestock farming is a subsector in agriculture that plays a significant role to support Indonesia's economy. As the population growth is accelerating and the education background of society in general has become higher, the income rate also improves, and the consumption of livestock products increases.

Eggs as one of poultry products contain high protein as the building blocks and regulators in the human body. As a fuel, protein is burned when carbohydrates and fat cannot fulfil energy demand in the body.

The Central Bureau of Statistics, Indonesia BPS (2019) reported in 2019 an increased consumption of free-range eggs by $2.59 \%$ per capita from 2015 through 2018 (1.940, 1.983, 2.119, $2.152 \mathrm{~kg}$ per capita, respectively). High consumption of free-range eggs in Purworejo is potentially developed by business stakeholders, from breeders to retailers who deliver the products to the consumers. The availability of free-range eggs is assessed from the convenience and freedom of the consumers to access the product in traditional and modern markets.

There are many contributing factors to consumer behaviour in purchasing goods, so the present study aims to analyse the buying decision process and the implication on the marketing mix of free-range eggs in Purworejo district. It was in line with Melly et al. (2017) that the factors to marketing mix analysis are buying decisions, quality, price, market cleanliness, and recommendation from friends or family. Information and evaluation are vital to formulating marketing strategies to achieve more effective services that conform to the consumers' need and taste (Kotler and Armstrong., 2008).

\section{Materials and Methods}

The study was conducted to wholesalers and retailers of free-range eggs in markets in
Purworejo, Central Java from June through November 2019. The sample was selected using a snowball sampling which started from a few consumers who recruited other consumers to make up a larger sample. The study spread a form of questionnaire to household consumers of free-range eggs.

The obtained data were subjected to validity and careful analysis of the product attributes. The data were analysed descriptively using ChiSquare to examine the relationship between the variables, i.e. age, marital status, gender, and occupation of consumers with the sellers, and Mann-Whitney to test the difference between consumers of wholesalers and retailers. Customer Satisfaction Index (CSI) was employed to examine the satisfaction index of the consumers of free-range eggs, and IPA was used to illustrate the combination of importance and performance based on the respondent's rate.

\section{Results and Discussions}

General characteristics of the respondents

The study observed different characteristics among consumers of free-range eggs on wholesalers and retailers scale regarding age, marital status, education background, occupation, and geographic location. The retailer consumers were older than those of wholesalers. Married consumers bought the eggs from both sellers, and consumers with a higher education background preferred buying eggs from retailers.

The different process of buying decisions was due to need identification, information gathering, evaluating the alternatives, and purchase.

On the stage of information gathering, the wholesaler consumers obtained information from the electronic media and neighbours, whereas those of retailers were from neighbours only. On the next stage (evaluating the alternatives), the main consideration to purchase free-range eggs for wholesaler 
consumers was the cleanliness of eggs, while for the retailer consumers were cleanliness and price of free-range eggs.

The purchasing process in wholesalers and retailers was dependent on the situation, so the time of buying is indefinite. The consumers bought eggs from retailers because the location is close to their house, but they bought eggs from wholesalers for quality. A previous study by Darwanti et al. (2014) reported that in two salted eggs producers, "Chozin" and "Rahayu", most consumers are women (62\% vs. $56 \%$ ), who are high school graduates ( $46 \%$ vs. $52 \%$ ) and businesswomen ( $42 \%$ vs. $40 \%$ ) and buy eggs from the nearest store.

Analysis of Customer Satisfaction Index (CSI) in Wholesaler level

Calculating Customer Satisfaction Index (CSI) in Wholesalers

$C S /$ value is determined based on the level of importance and attribute performance of freerange eggs in wholesaler was $65.16 \%$ (Satisfied category) in a range of 60 to $80 \%$.

Attributes with the highest rate of consumer's importance in wholesalers were aroma and cleanliness of free-range eggs (4.00 and 3.94, respectively). It is indicative of consumers' high expectation on aroma and cleanliness of the eggs. Accordingly, improving the score of these attributes would increase the consumer satisfaction index. Regarding performance, discount price had the lowest mean (0.17), so it did not significantly contribute to improving the CSI. Wulandari et al. (2019) stated that the respondents' decision is executed in their action to buy a product through a process involving need identification, information seeking, evaluating the alternatives, buying decision, and postpurchase evaluation. Meanwhile, Tumbel dan Van Rate, (2015) reported a difference in the buying decision process regarding need identification, evaluating the alternatives and the purchase.

\section{Calculating Customer Satisfaction Index (CSI) in Retailers}

The result showed that the CSI in retailers is higher than that of the wholesaler, i.e. $68.82 \%$. This score is within 'satisfied' criteria because it falls between the range of $60-80 \%$.

Attributes with the highest mean of importance are aroma and cleanliness of freerange eggs, which indicates a high contribution to improving CSI. Meanwhile, discount is the lowest performance for the wholesaler consumers (0.12). It shows that the discount did not significantly contribute to improving consumer satisfaction. A previous study (Wulandari et al., 2019) reported an overall CSI (92.00\%) in 'satisfied' criteria regarding the price, cleanliness, packaging and size. Meanwhile, Novita et al. (2014) reported the CSI value of the marketing mix of Belt mart Bogor is $76.83 \%$ satisfied.

\section{IPA Diagram (Importance Performance Analysis)}

IPA Diagram is the combination of importance and performance values based on consumer's ratings. The relationship between the two values is useful for mapping the priority of attribute improvement based on the quadrant of each attribute.

Based on the Cartesian Diagram in Figure 1, the data interpretation of wholesaler respondents is presented in Table 1 below.

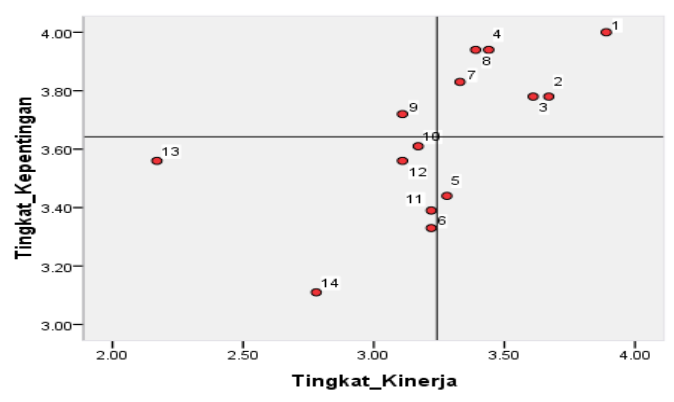

Figure 1. IPA Diagram for Wholesalers 
Table 1. Result of the Importance and Performance Analysis in Wholesalers

\begin{tabular}{clll}
\hline \multicolumn{1}{c}{ Quadrant I } & \multicolumn{1}{c}{ Quadrant II } & \multicolumn{1}{c}{ Quadrant III } & \multicolumn{1}{c}{ Quadrant IV } \\
\hline Availability (9) & Aroma (1) & Egg variation (6) & \\
& Texture (2) & Ease (10) & \\
& Colour (3) & Convenience (11) & \\
& Cleanliness (4) & Service (12) & \\
& Price-quality match (7) & Discount (13) \\
& Price affordability (8) & Promotion (14) & \\
\hline
\end{tabular}

Table 2. Result of Importance Performance Analysis of Retailers

\begin{tabular}{clll}
\hline \multicolumn{1}{c}{ Quadrant I } & \multicolumn{1}{c}{ Quadrant II } & \multicolumn{1}{c}{ Quadrant III } & \multicolumn{1}{c}{ Quadrant IV } \\
\hline Availability (9) & Aroma (1) & Egg variations (6) & Packaging (5) \\
& Texture (2) & Convenience (11) & \\
Colour (3) & Service (12) \\
& Cleanliness (4) & Discount (13) \\
& Price-quality match (7) & Promotion (14) \\
& Price affordability (8) & \\
& Ease (10) & \\
\end{tabular}

The result of the IPA diagram of retailers is presented in Figure 2 below.

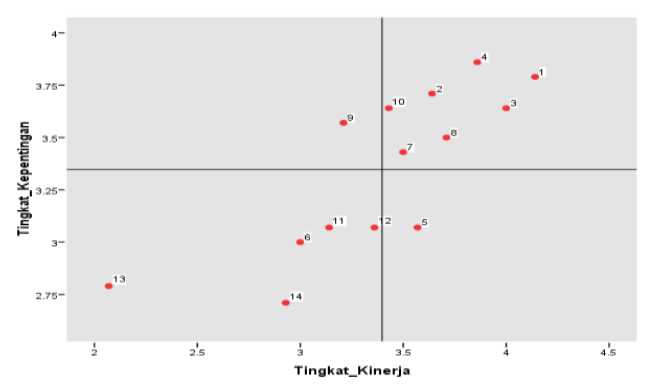

Figure 2. IPA Diagram of Retailers

Based on the Cartesian Diagram in Figure 2, the data interpretation of retailer respondents is presented in Table 2 below

The priorities of attribute improvement based on each position in both markets on IPA quadrants are below:

\section{a. Quadrant I (main priority)}

Attributes in Quadrant 1 show a high importance rate, but the performance is under the consumer's expectation. Accordingly, the attributes that fall into this quadrant are the main priority for improvement, to increase the consumer's satisfaction.

The attribute in wholesalers and retailers that is encompassed in Quadrant 1 is the availability of free-range eggs. The consumers of wholesalers and retailers stated that the availability of free-range eggs in the marketplace is an important factor to consider, but it has not met the consumers' expectations.

\section{b. Quadrant II (maintenance performance)}

Quadrant II contains attributes with high importance and the performance is rated well by the consumers. The sellers should maintain the attributes that fall into this category in order to improve the sale of free-range eggs.

The aroma of free-range eggs in both sellers is considered to have reflected the fresh aroma of eggs. Also, the egg texture in both sellers is rated good for its quality, such as an intact egg yolk in the white.

The cleanliness of eggs falls into Quadrant II because the eggs, according to consumers, are clean and separated from the other products. Both types of sellers are considered to have put an affordable price that matches the quality. The consumers often associate the price with the quality of a product. Therefore, the effort to maintain this attribute in Quadrant $\|$ is to remain honest with the consumers about the eggs. 


\section{c. Quadrant III (low priority)}

Quadrant III contains attributes with low importance and average performance as perceived by the consumers (Hair, et al., 2019).

The variation of free-range eggs in both wholesalers and retailers falls into Quadrant III, so it is considered of low importance although the performance has met the consumers' expectations. Also, the consumers in wholesaler perceive that the importance level of the realtime availability of eggs has been fulfilled (Astuti et al., 2019) so that it provides ease for the consumers.

The convenience attribute in both wholesalers and retailers falls into low priority. The seller service is rated of low priority by the consumers because of the condition in the traditional market. Also, the consumers perceive service as of low importance, so it does belong to the priority for improvement. Nevertheless, the sellers should maintain their best service to satisfy the consumers.

The discount price attribute has a low level of importance and performance because the discount applies to the stale product. The consumers trust both sellers because the egg price would affect the quality. An excessive discount would make the consumers doubt the quality of the free-range eggs.

The promotion attribute is perceived to have low importance. Consumers in both sellers stated that they rely on their experience when buying free-range eggs from a store.

\section{d. Quadrant IV (overacting)}

The packaging of free-range eggs in wholesalers or retailers is perceived to have low importance and performance because the consumers suggest that plastic containers are sufficient to contain and protect the eggs.

Similarly, Wulandari et al. (2019) reported a consumer satisfaction index of $92.67 \%$ in the range of $50-10 \%$ (satisfied category) regarding price, cleanliness and size.

On the other hand, Novita et al. (2014) mentioned a difference across attributes in
Quadrant IV, i.e. variation of price, product, discount price, uniform and lighting. However, these attributes are considered to have low importance and the performance has met the consumers' expectation.

\section{Implication of marketing mix}

\section{Product mix}

Analysis of the IPA diagram shows that the availability of free-range eggs is an attribute that requires priority improvement in both wholesalers and retailers because they collect eggs from the closest suppliers to their home; consequently, the daily supply of free-range eggs is not stable. It is suggested that wholesalers and retailers reorganize the schedule to order eggs to the suppliers and maintain good collaboration with the suppliers to ensure the real-time availability of free-range eggs. It takes a good production, dedication, and uniqueness to meet customer demand. (Engel, 2001).

Meanwhile, (Nasir, 2013) stated that the packaging label needs to contain information about the product, availability, description of ingredients, expiry date, and safety assurance for consumers. Furthermore Panjaitan and Cahyanto, (2017) reported that product plays a role in buying decisions. Accordingly, product is the main priority for improvement to increase buying decisions (Heryanto, 2015). Aras et al. (2017) stated that quality products would improve the rate of product sale.

\section{Price mix}

Based on the IPA diagram on wholesalers and retailers, the selling price of the free-range eggs is affordable and matches the egg quality. The respondents stated that they would still buy the eggs although the price increased because they pose a high demand for freerange eggs. Even so, the seller cannot increase the price as they wish because of the competition in the egg market.

Quadrant III contains the discount price attributes in both wholesalers and retailers, 
indicative of low priority for improvement and performance. It shows that cheap free-range eggs are not the solution to consumers' dissatisfaction. Therefore, the sellers need to be careful when giving a discount without risking the quality of the free-range eggs. An excessive discount would make the consumers perceive a decreased quality in the eggs. Further, Nasir (2017) stated that the production price is very efficient as observed from the product price and stable price. On the other hand, Novita et al. (2014) reported variable which is not the priority to be improved i.e. performance, price, advertisement and sale promotion. Furthermore according to Tjiptodjojo (2012) that the retail prices are often expressed as odd price or psychological pricing techniques. Panjaitan and Cahyanto (2017) mentioned the role of price in affecting buying decisions - if the price increases, the purchase decreases. Therefore, price is a priority that needs to be improved (after product priority) to increase buying decisions (Heryanto, 2015). Also, Aras et al. (2017) argued that price is a significant contributing factor to consumers' decision to own a product.

\section{Distribution mix}

Based on the IPA diagram, the marketplace conventional for consumers of both wholesalers and retailers is contained in Diagram III. It demonstrates that this attribute is below expectation and of low importance because the purpose of consumers going to market is for shopping without bothering the condition of the traditional market.

Improving convenience attributes should be the responsibility of both sellers and market management of the traditional markets in Purworejo to create a more comfortable ambiance. The respondents of both wholesalers and retailers perceived product availability in Quadrant I because the availability of freerange eggs in the market is important but has not met the consumers' expectations. The sellers should reschedule their orders to the suppliers and maintain good collaboration to ensure the real-time availability of free-range eggs. This result is supported by Nasir (2017) that distribution activity includes collecting the eggs, selecting eggs based on particular criteria, and then distributing the eggs. Meanwhile, Panjaitan and Cahyanto, (2017) mentioned the important role of promotion in buying decisions. Accordingly, distribution is a priority that needs to be improved (after product and price) to increase buying decisions (Heryanto, 2015).

\section{Promotion mix}

Promotion attribute is observed in both wholesalers and retailers. The study showed that the consumers in both sellers are relying on their experience and memory when seeking information. They are not interested in promotion. The level of performance in both sellers is perceived normal, and both sellers are not active to promote their products.

Nasir (2017) stated that promotion is conducted using a word-of-mouth strategy (Word of Mouth Communication). The researcher argued that promotion is a persuasive message to advertise a product to target clients, so they are interested in the product. However, Tumbel dan Van Rate, (2015) reported differently. The analysis of the buying decision process on the level of need identification and processing information showed that promotion affects the product, price, and distribution, although not significant. In contrast, Panjaitan and Cahyanto (2017) argued that the effect of promotion on these variables are significant, even promotion is the most dominant factor in buying decisions. Accordingly, promotion is a priority for improvement (after product, price, and distribution) to increase buying decisions (Heryanto, 2015). Also, Aras et al. (2017) stated that promotion is indirect marketing so that the 
consumers could access the marketplace more easily.

\section{Conclusions}

The consumers in retailers are mostly housewives, more educated, mostly entrepreneurs and older than those in wholesalers. Buying decisions of the wholesalers regarding information seeking are more variable than that of retailers. The retailers put more emphasis on the price as far as evaluating the buying alternatives. Both wholesalers and retailers are satisfied based on the consumer satisfaction index. The implication of marketing mix in both sellers include improving the cleanliness of free-range eggs and the marketplace, matching the egg price with market price to maintain competitiveness, harnessing quality control of free-range eggs from the suppliers, and managing the supply chain management to maintain the real-time availability of free-range eggs.

\section{References}

Aras, M., H. Syam., Jasruddin., H. Akib, and H. Haris. 2017. The Effect of Service Marketing Mix on Consumer Decision Making. Proceeding International Conference on Education Science, Art and Technology. 1(1): 108-112.

Astuti, F. K., K. S. Surot, and E. P. Santoso. 2019. Analisis Bauran Pemasaran Terhadap Perilaku Konsumen Daging Sapi Dan Implikasi Strategi Pemasaran Di Hypermarket Kota Malang. Buana Sains. 19 (1): 25-36.

BPS. Purworejo. 2019. Kabupaten Purworejo Dalam Angka 2017. Kabupaten Purworejo: BPS Kabupaten Purworejo.

Darwanti, F., B. A. Nugroho, and H. D. Utami. 2014. Analisis Pengaruh Bauran Pemasaran terhadap Keputusan Pembelian dalam Membeli Telur Asin CHOSIN dan Rahayu di Kecamatan Babat Kabupaten Lamongan.

Engel. 2001. Consumer Behavior.Orlando, Florida Harcourt College Publisher.
Hair, J. F., W. C. Black., B. J. Babin, and R. E. Anderson. 2019. Multivariate data analysis, 7th Edition. Englewood Cliffs. NJ: Prentic. 5(3): 207-219.

Heryanto, I. 2015. Analisis Pengaruh Produk, Harga, Distribusi dan Promosi terhadap Keputusan Pembelian serta Implikasinya pada Kepuasan Pelanggan. Jurnal Ekonomi, Bisnis \& Entrepreneurship. 9(2): 80-101.

Kotler P. and G. Armstrong. 2008. Prinsip-Prinsip Pemasaran. Jilid 2. Edisi ke-12 Jakarta (ID): Penerbit Erlangga. Terjemahan dari: Principles of Marketing.

Melly, R., B. A. Nugroho, and B. Hartono. 2017. Analisis Bauran Pemasaran dalam Membeli Ayam Goreng di Lalapan Kalpataru dan Cak Yono Tlogomas Malang. Jurnal Ilmu-ilmu Peternakan. 23 (1): 30-34.

Nasir, M. 2017. Studi Perilaku Konsumen terhadap Keputusan Pembelian Air Minum Aqua di Kota Surakarta. Benefit: Jurnal Manajemen dan Bisnis. 12(1): 57-83.

Nasir, M. 2013. Metode Penelitian. Bogor (ID): Penerbit Ghalia Indonesia.

Novita, I., T. Megasari, dan A. Yoesdiarti. 2014. Analisis Tingkat Kepuasan Konsumen terhadap Bauran Pemasaran Belt Mart Bogor. Journal Pertanian. 5(1): 11-21.

Panjaitan, H. and H. Cahyanto. 2017. Analisis Pengaruh Bauran Pemasaran terhadap Keputusan Pembelian Pakan Ternak Ayam Pedaging di Kabupaten Jombang Jawa Timur. Jurnal Ilmu Ekonomi \& Manajemen. 4(1): 1423.

Tjiptodjojo, K. I. 2012. Odd Price : harga, Psikologi dan Perilaku Konsumen dalam Purchase Decision Making. Jurnal Manajemen Maranatha. 11(2): $141-150$

Tumbel, A. L. dan P. Van Rate. 2015. Pengaruh Bauran Pemasaran terhadap Keputusan Pembelian di Pasar Tradisional (Studi Pada Pasar Tradisional di Kota Manado. Jurnal LPPM Bidang EkoSosBudKum. 2(2).60-72.

Wulandari, W., C. Vermila, dan N. Hadi. 2019. Analisis Kepuasan Konsumen Telur di Pasar Rakyat Teluk Kuantan Kecamatan Kuantan Tengah Kabupaten Kuantan Singingi. Agriture. Journal Agribusiness Future. 1(2): 148-157. 